\title{
Agronomic performance of rootstocks on the juice grape 'BRS Magna' grown in a Brazilian semi-arid region
}

\begin{abstract}
Patrícia Coelho de Souza Leão ${ }^{1}$, Marcos Andrei Custódio da Cunha², Edimara Ribeiro de Souza ${ }^{3}$
Abstract - Rootstocks are widely used in viticulture worldwide and can affect the yield components and quality of grapes and their juices and wines. The aim of the present study was to determine the effect of the rootstock on the yield performance and physical and physical-chemical traits of 'BRS Magna' juice grapes grown in the Submédio do Vale do São Francisco. The study was performed over six production cycles in the period from 2015 to 2019 in the Bebedouro experimental field of Embrapa Semiárido in Petrolina, PE, Brazil. The treatments consisted of seven grapevine rootstocks: IAC 572, IAC 766, IAC 313, Paulsen 1103, SO4, Harmony, and Freedom. The following variables were evaluated: estimated yield, number of grape bunches per plant, branch and leaf fresh matter, bunch weight, bunch length and width, berry weight, total soluble solids content (SS), titratable acidity (TA), and SS to TA ratio (SS:TA). Significant effects of the rootstock were observed in all the variables except for SS. The rootstock 'IAC 572' led to increases of up to $61 \%$ in the yield of 'BRS Magna' grapevines, or 32.78 ton. ha ${ }^{-1}$, with significant responses in the other yield components. Results of the scatterplot in relation to the first three principal components allowed separation of the rootstocks in accordance with production cycles. The mean values for SS and TA characterize this cultivar in the Vale do Submédio São Francisco, with high soluble solids content and low acidity resulting in high SS:TA, as having potential for preparation of high quality juices, regardless of the rootstock used.
\end{abstract}

Index terms: grafting, scion, tropical viticulture, vine.

\section{Desempenho agronômico de videira 'BRS Magna' enxertada em diferentes porta-enxertos no semiárido Brasileiro}

\begin{abstract}
Corresponding author: patricia.leao@embrapa.br

Received: August 02, 2021 Accepted: September 09, 2021

Copyright: All the contents of this journal, except where otherwise noted, is licensed under a Creative Commons Attribution License.
\end{abstract}

\section{(cc) $\mathbf{E Y}$}

Resumo - Porta-enxertos são amplamente utilizados na viticucultura mundial e podem influenciar os componentes de produção e a qualidade das uvas, dos sucos e dos vinhos. O objetivo do presente trabalho foi determinar a influência do porta-enxerto no desempenho produtivo, nas características físicas e físico-químicas de uvas para suco 'BRS Magna', cultivadas no Vale do Submédio São Francisco. O estudo foi realizado durante seis ciclos de produção, no período de 2015 à 2019, no Campo Experimental de Bebedouro da Embrapa Semiárido, em Petrolina-PE. As seguintes variáveis foram avaliadas: produtividade estimada; número de cachos por planta; massa fresca de ramos e de folhas; massa do cacho; comprimento e largura do cacho; massa da baga; teor de sólidos solúveis totais (SS), acidez titulável (AT) e relação SS/AT. Efeitos significativos do porta enxerto foram observados em todas as variáveis, com exceção do teor de SS. O porta-enxerto IAC 572 promoveu aumentos de até $61 \%$ na produtividade de videiras 'BRS Magna', com respostas significativas nos demais componentes de produção. A dispersão gráfica em relação aos três primeiros componentes principais permitiu a separação dos porta-enxertos em função dos ciclos de produção. Os valores médios para teor de SS e de AT caracterizam esta cultivar no Vale do Submédio São Francisco, com alto conteúdo de sólidos solúveis e baixa acidez, resultadar em elevada relação SS/AT, com potencial para elaboração de sucos de elevada qualidade, independentemente do porta-enxerto utilizado.

Termos para indexação: enxertia, copa, viticultura tropical, videira.

\footnotetext{
${ }^{1} \mathrm{PhD}$ in Genetics and Plant Breeding, Embrapa Semi-Arido, Petrolina-PE, Brazil. E-mail: patricia.leao@embrapa.br (ORCID:0000-0003-4025-6257) ${ }^{2}$ Graduate Student, Universidade de Pernambuco, Petrolina-PE, Brazil. E-mail: andreymarcos347@gmail.com (ORCID: 0000-0003-3986-0078) ${ }^{3}$ Undergraduate student, Universidade do Recôncavo da Bahia, Cruz das Almas-BA, Brazil. E-mail: edimara21ribeiro@gmail. $\operatorname{com}^{\text {ORCID }: 0000-0002-9957-9045)}$
} 


\section{Introduction}

Grape juice production increased in the past decade by around $122 \%$ in the state of Rio Grande do Sul, Brazil, passing from 131 million liters in 2009 to 290.2 million liters in 2019 (Mello and Machado, 2019). Grape growing has advanced to other regions of Brazil beyond Rio Grande do Sul, such as the Vale do Submédio São Francisco.

The BRS Magna cultivar was developed by the Embrapa grape breeding program and is recommended for commercial growing to improve the color, sugar content, and flavor of Brazilian grape juices (RITSCHEL et al., 2014). In the Vale do Submédio São Francisco, 'BRS Magna' grapevines yield around 60 ton.ha ${ }^{-1}$ in two production cycles a year (LEÃO et al., 2018); these grapes are rich in phenolic compounds and antioxidant activity (LIMA et al 2014). Nevertheless, considering the particular aspects of tropical viticulture, adjustments in the production system are necessary to achieve yield potential and ensure the quality of the grapes and juices.

The rootstock is known to be important in viticulture through its effects on yield, grape quality, and the products prepared from different cultivars and production regions.

Results of studies in different grape-growing regions of Brazil have shown that the response of the grapevine to the rootstock is specific and depends on the combination between scion and rootstock cultivars, as well as on their interaction with the edaphic and climatic conditions of each region.

Grapes of 'BRS Magna' grafted on 'IAC 572' had greater antioxidant activity and greater total extractable polyphenol content compared to 'IAC 766' (FERREIRA et al; 2019). However, Silva et al. (2018) found that the rootstock 'IAC 766' led to greater sugar content in juices of 'Isabel Precoce', 'BRS Cora', and 'IAC 138-22 Máximo', as well as greater anthocyanin and t-resveratrol content in juices of 'IAC 138-22 Máximo'.

The recent results of studies performed in different Brazilian production regions and juice grape cultivars show that the rootstock plays an important role in improving quality attributes of Brazilian juices. However, there is no information available from research related to the agronomic performance of the BRS Magna cultivar as affected by the rootstock. Thus, the aim of this study was to determine the effect of the rootstock on the yield, vigor, and physical and physical-chemical traits of 'BRS Magna' grapes grown in the Vale do Submédio São Francisco.

\section{Materials and Methods}

The experiment was conducted in the Bebedouro experimental field belonging to Embrapa Semiárido, Petrolina, PE, Brazil (0909' S, 40²2' W, and mean altitude of 365.5 meters above sea level) over six production cycles from 2015 to 2019. According to the Köppen classification, the climate in the region is Bswh, which corresponds to a very hot semi-arid region (ALVARES et al., 2014), with mean annual temperature of around $26^{\circ} \mathrm{C}$, relative humidity of $64 \%$, mean annual rainfall of around

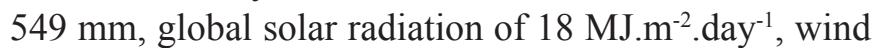
speed of $2 \mathrm{~m} . \mathrm{s}^{-1}$, and reference evapotranspiration (ETo) of $6 \mathrm{~mm}^{-d_{a y}{ }^{-1}}$ (TEIXEIRA, 2010). The mean monthly values of mean, maximum, and minimum air temperature $\left({ }^{\circ} \mathrm{C}\right)$, global solar radiation $\left(\mathrm{MJ} \cdot \mathrm{m}^{-2} \cdot \mathrm{day}^{-1}\right)$, and rainfall (mm) for the years 2015 to 2019 were obtained from the automatic agrometeorological station of the Bebedouro experimental field and are shown in Figure 1.

The soils of the location were classified as Argissolo Vermelho Eutrófico Abrúptico Plíntossólico with moderate A horizon, medium texture, and flat topography (CUNHA et al., 2008).

A pergola vine training system was used, with $3 \times 2$ $\mathrm{m}$ spacing between plants (density of 2666 plants/ha) and drip irrigation system with two emitters per plant at every $0.50 \mathrm{~m}$ and mean flow of $2.10 \mathrm{~L} . \mathrm{h}^{-1}$. The gross water depth values were calculated daily, using the ETo determined by the Class A pan method (ALLEN et al, 1998).

The grapevines were pruned in a unilateral cordon, performing two prunings per year of the mixed type, with spurs at the base of the branches and canes with 7 or 8 bud length. Crop treatments included sprouting, tying of branches and shoots, weed control through herbicide application, mowing between rows, and weekly plant health control.

The experimental treatments consisted of seven rootstocks: 'Freedom', 'Harmony', 'IAC 313', 'IAC 766', 'IAC 572', 'Paulsen 1103', and 'SO4', which were chosen for being those most commonly used in the Vale do Submédio São Francisco.

The experimental design was randomized blocks, with four replications; a plot consisted of five plants, using two plants in the center for data collection through harvest and evaluation of the fruit. Fruit was harvested when fully ripe.

The branches and leaves eliminated during pruning in the plants used for data collection were separated and weighed to record branch and leaf fresh matter, expressed in kg.plant ${ }^{-1}$, which is a variable used to indicate grapevine vigor. 
At the time of harvest, the bunches were counted and weighed on a digital electronic balance. The mean results obtained were expressed in kg.plant ${ }^{-1}$ and were used to estimate yield in ton.ha ${ }^{-1}$ by the product of mean yield per plant and number of plants per hectare. The mean weight of the bunch, expressed in grams (g), was obtained by dividing the total weight of bunches per plant by the number of bunches per plant. A sample of five bunches per plot were harvested for evaluation of bunch length and width using a ruler, and measurements were expressed in centimeters $(\mathrm{cm})$. Berry weight, expressed in grams, was determined from a sample of 10 berries collected from each bunch, for a total of 50 berries per plot. The same sample was used for must extraction for determination of total soluble solids content (SS) and titratable acidity (TA). The SS was measured in a digital refractometer and expressed in ${ }^{\circ}$ Brix; titration was carried out with $0.1 \mathrm{~N}$ $\mathrm{NaOH}$ (AOAC, 2010) for determination of TA, and the results were provided in percentage of tartaric acid (\%).
The mean values of the five production cycles were calculated for all the variables studied; the Shapiro-Wilk normality test was then performed on these values. Data of branch and leaf fresh matter did not show a normal distribution and were transformed by $\sqrt{\mathrm{x}+1}$. Analysis of variance ( $\mathrm{F}$ test, $p<.05$ ) and means comparison by Tukey's test $(p<.05)$ were carried out on data that fulfilled the requirement of a normal distribution. Multivariate principal component analysis was carried out on the mean data from five production cycles.

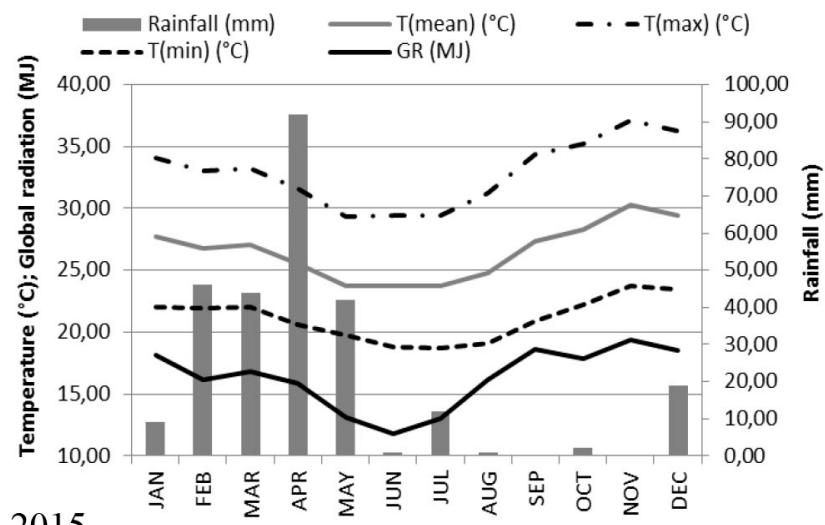

2015

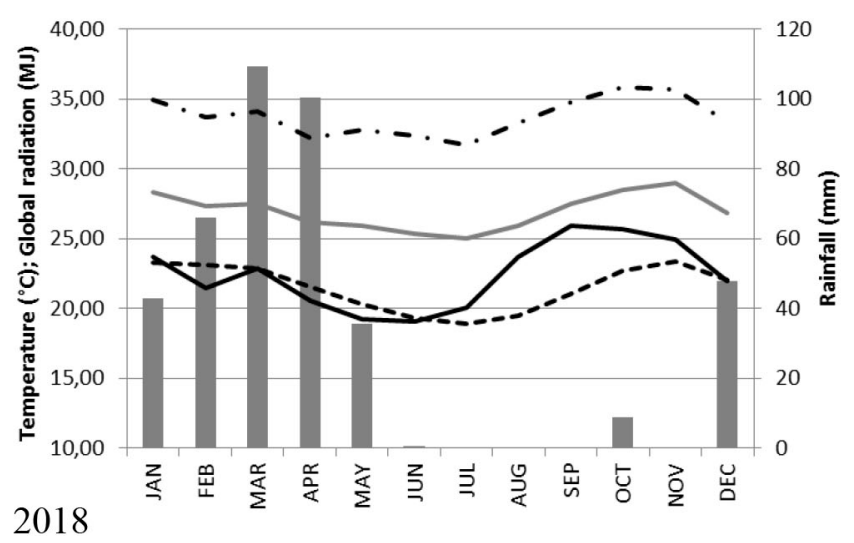

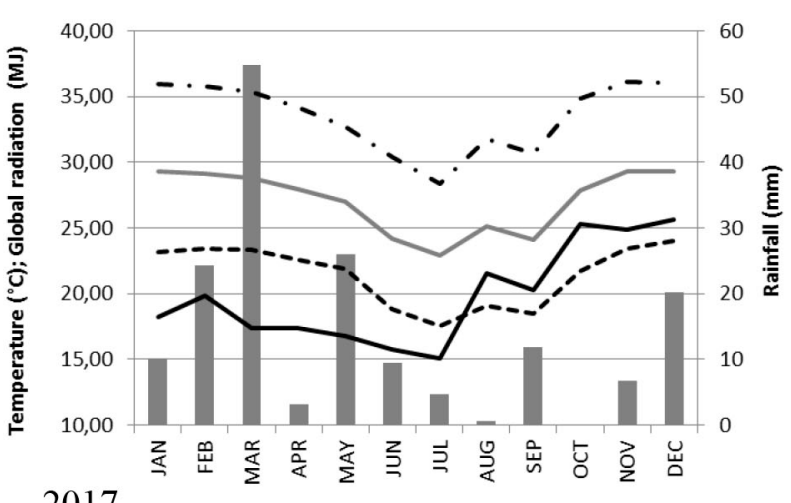

2017

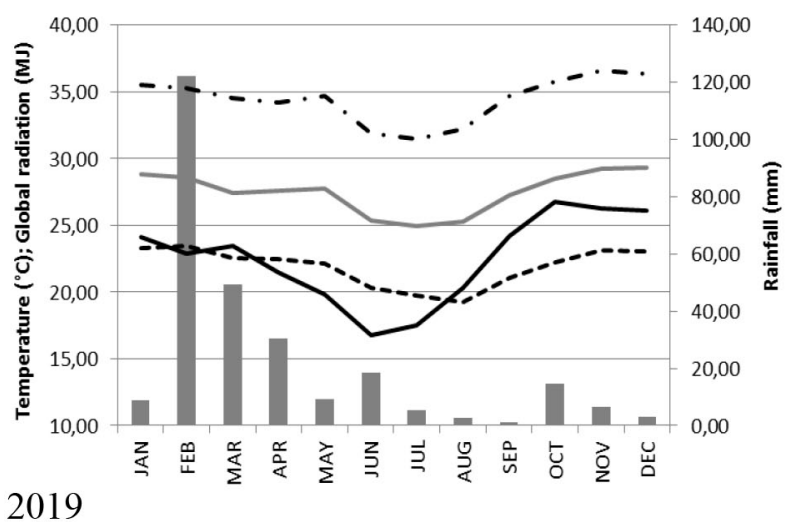

Figure 1. Seasonal rainfall variations ( $\mathrm{mm}$ ); average (Tmean), minimum (Tmin), and maximum (Tmax) temperature $\left({ }^{\circ} \mathrm{C}\right)$; and global radiation (GR) $\left(\mathrm{MJ} \mathrm{m}^{-2}\right)$, during the period of 2015 to 2019 in the experimental station of Bebedouro, Petrolina, PE, Brazil. 


\section{Results and Discussion}

The rootstock affected the agronomic performance differences were observed in all the variables, except for soluble solids content (Tables 1, 2 and 3). of the 'BRS Magna' grapevines; significant statistical

Table 1. Mean values ${ }^{1}$ and coefficients of variation for yield, number of bunches, bunch weight, and branch and leaf fresh matter of 'BRS Magna' vines on different rootstocks, Petrolina, PE, Brazil, 2015 to 2019.

\begin{tabular}{lcccc}
\hline Rootstock & $\begin{array}{c}\text { Yield } \\
\text { (ton.ha }^{-1} \text { ) }\end{array}$ & $\begin{array}{c}\text { Number of } \\
\text { bunches }\end{array}$ & $\begin{array}{c}\text { Bunch weight } \\
(\mathbf{g})\end{array}$ & $\begin{array}{c}\text { Branch and leaf fresh } \\
\text { matter }^{\mathbf{(}} \text { kg.plant }^{-1} \text { ) }\end{array}$ \\
\hline Freedom & $19.81 \pm 3.22 \mathrm{bc}$ & $85 \pm 13.32 \mathrm{bc}$ & $173.65 \pm 32.64 \mathrm{bc}$ & $1.10 \pm 0.33 \mathrm{ab}$ \\
Harmony & $18.18 \pm 6.16 \mathrm{~cd}$ & $89 \pm 16.22 \mathrm{bc}$ & $155.92 \pm 26.88 \mathrm{c}$ & $1.80 \pm 0.82 \mathrm{ab}$ \\
IAC 313 & $24.75 \pm 1.66 \mathrm{bc}$ & $96 \pm 5.90 \mathrm{abc}$ & $199.73 \pm 6.09 \mathrm{ab}$ & $1.30 \pm 0.29 \mathrm{ab}$ \\
IAC 766 & $25.66 \pm 1.44 \mathrm{ab}$ & $110 \pm 5.11 \mathrm{ab}$ & $190.06 \pm 7.35 \mathrm{abc}$ & $1.57 \pm 0.52 \mathrm{ab}$ \\
IAC 572 & $32.78 \pm 3.12 \mathrm{a}$ & $118 \pm 10.16 \mathrm{a}$ & $220.07 \pm 31.54 \mathrm{a}$ & $2.13 \pm 0.54 \mathrm{a}$ \\
P1103 & $24.26 \pm 3.77 \mathrm{bc}$ & $107 \pm 22.13 \mathrm{ab}$ & $186.62 \pm 14.49 \mathrm{abc}$ & $1.15 \pm 0.43 \mathrm{ab}$ \\
SO4 & $12.58 \pm 0.68 \mathrm{~d}$ & $72 \pm 7.87 \mathrm{c}$ & $151.71 \pm 32.18 \mathrm{c}$ & $0.80 \pm 0.21 \mathrm{~b}$ \\
\hline Mean & $\mathbf{2 2 . 5 7 \pm 6 . 7 4}$ & $\mathbf{9 7} \pm \mathbf{1 8 . 9 8}$ & $\mathbf{1 8 2 . 5 4} \pm \mathbf{3 1 . 2 8}$ & $\mathbf{1 . 4 1} \pm \mathbf{0 . 6 1}$ \\
\hline CV(\%) & $\mathbf{1 3 . 6 3}$ & $\mathbf{1 1 . 8 1}$ & $\mathbf{1 0 . 1 1}$ & $\mathbf{9 . 1 1}$ \\
\hline
\end{tabular}

${ }^{1}$ Mean values followed by the same lowercase letter in the column do not differ by Tukey's test at $5 \%$ probability; ${ }^{2}$ Data transformed by $\sqrt{\mathrm{x}+1}$

Table 2. Mean values and coefficients of variation for bunch width and length and berry weight of cv. BRS Magna grapes on different rootstocks, Petrolina, PE, Brazil, 2015 to $2019^{1,2}$.

\begin{tabular}{lccc}
\hline Rootstock & $\begin{array}{c}\text { Bunch } \\
\text { width } \mathbf{( c m})\end{array}$ & $\begin{array}{c}\text { Bunch } \\
\text { length (cm) }\end{array}$ & $\begin{array}{c}\text { Berry } \\
\text { weight(g) }\end{array}$ \\
\hline Freedom & $11.63 \pm 0.80 \mathrm{bc}$ & $7.59 \pm 0.29 \mathrm{ab}$ & $2.46 \pm 0.15 \mathrm{ab}$ \\
Harmony & $11.90 \pm 0.61 \mathrm{bc}$ & $7.58 \pm 0.14 \mathrm{ab}$ & $2.40 \pm 0.11 \mathrm{~b}$ \\
IAC 313 & $12.52 \pm 0.46 \mathrm{ab}$ & $7.96 \pm 0.51 \mathrm{ab}$ & $2.66 \pm 0.15 \mathrm{ab}$ \\
IAC 766 & $12.32 \pm 0.47 \mathrm{ab}$ & $8.20 \pm 0.52 \mathrm{ab}$ & $2.52 \pm 0.09 \mathrm{ab}$ \\
IAC 572 & $13.49 \pm 0.52 \mathrm{a}$ & $8.67 \pm 0.07 \mathrm{a}$ & $2.69 \pm 0.21 \mathrm{a}$ \\
Paulsen 1103 & $11.91 \pm 0.31 \mathrm{bc}$ & $8.01 \pm 0.99 \mathrm{ab}$ & $2.53 \pm 0.06 \mathrm{ab}$ \\
SO4 & $10.91 \pm 0.52 \mathrm{c}$ & $7.03 \pm 0.63 \mathrm{~b}$ & $2.64 \pm 0.08 \mathrm{ab}$ \\
\hline Mean & $\mathbf{1 2 . 1 0} \pm \mathbf{0 . 9 0}$ & $\mathbf{7 . 8 6} \pm \mathbf{0 . 6 8}$ & $\mathbf{2 . 5 6} \pm \mathbf{0 . 1 5}$ \\
\hline CV (\%) & $\mathbf{4 . 4 1}$ & $\mathbf{6 . 7 3}$ & $\mathbf{4 . 6 1}$ \\
\hline
\end{tabular}

${ }^{1}$ Mean values followed by the same lowercase letter in the column do not differ by Tukey's test at $5 \%$ probability; ${ }^{2}$ ns: not significant

Table 3. Mean values and coefficients of variation for soluble solids content (SS), titratable acidity (TA), and the SS and TA ratio (SS:TA) of cv. BRS Magna grapes on different rootstocks, Petrolina, PE, Brazil, 2015 to 2019 2.

\begin{tabular}{lccc}
\hline Rootstock & $\begin{array}{c}\text { SS } \\
\left({ }^{\circ} \mathbf{B r i x}\right)\end{array}$ & $\begin{array}{c}\text { TA } \\
(\mathbf{\%})\end{array}$ & SS:TA \\
\hline Freedom & $22.26 \pm 0.75^{\text {ns }}$ & $0.46 \pm 0.07 \mathrm{ab}$ & $49.64 \pm 8.69 \mathrm{a}$ \\
Harmony & $21.14 \pm 0.44$ & $0.43 \pm 0.04 \mathrm{~b}$ & $49.84 \pm 5.11 \mathrm{a}$ \\
IAC 313 & $21.55 \pm 0.14$ & $0.52 \pm 0.05 \mathrm{a}$ & $41.58 \pm \mathrm{ab}$ \\
IAC 766 & $21.23 \pm 0.48$ & $0.49 \pm 0.03 \mathrm{ab}$ & $43.29 \pm \mathrm{ab}$ \\
IAC 572 & $21.35 \pm 0.48$ & $0.51 \pm 0.04 \mathrm{ab}$ & $42.23 \pm \mathrm{ab}$ \\
Paulsen 1103 & $20.60 \pm 0.37$ & $0.53 \pm 0.02 \mathrm{a}$ & $38.77 \pm \mathrm{b}$ \\
SO4 & $20.67 \pm 1.10$ & $0.50 \pm 0.05 \mathrm{ab}$ & $41.93 \pm \mathrm{ab}$ \\
\hline Mean & $\mathbf{2 1 . 2 5} \pm 0.87$ & $\mathbf{0 . 4 9} \pm 0.05$ & $\mathbf{4 3 . 8 9} \pm$ \\
\hline CV (\%) & $\mathbf{3 . 4 4}$ & $\mathbf{8 . 4 4}$ & $\mathbf{9 . 7 7}$ \\
\hline
\end{tabular}

${ }^{1}$ Mean values followed by the same lowercase letter in the column do not differ by Tukey's test at $5 \%$ probability; ${ }^{2}$ ns: not significant 
The mean yield of grapevines grafted on 'IAC 572' was 32.8 ton.ha ${ }^{-1}$ per production cycle, not differing from 'IAC 766 ' $\left(25.7\right.$ ton.ha $\left.^{-1}\right)$. The mean yield was higher than that reported by Ritschel et al (2014), from 25 to 30 ton. ha $^{-1}$, in description of the cultivar, as well as higher than the yields reported for Isabel Precoce, BRS Carmem, BRS Cora, and IAC 138-22 Máximo (grape cultivars for processing) on two rootstocks, 'IAC 572' and 'IAC 766' (Silva et al., 2018), and higher than the yield reported for different clones of the Concord cultivar on the rootstocks ' 420 A', 'IAC 572', and 'IAC 766' (BORGES et al., 2014).

The 'IAC 572' rootstock increased yield in relation to the other rootstocks, with an increase of up to $61.6 \%$ compared to the 'SO4' rootstock. The yield performance of 'BS Magna' grapevines on different rootstocks decreased in the following order: 'IAC 572'> 'IAC 766'> 'IAC 313' $>$ 'P1103' > 'Freedom'> 'Harmony' > 'SO4' (Table 1). The results obtained are in agreement with those reported on the hybrid table grape cultivar Vênus, in which higher yield was also observed on the 'IAC 572' rootstock (TECCHIO et al. 2019a). Nevertheless, for the Concord cultivar, there was interaction between rootstocks and clones, showing the complexity of the factors involved in response to the rootstock (BORGES et al. 2014).

The number of bunches per plant had a response similar to that of yield, with the highest number of bunches for rootstocks 'IAC 572', 'IAC 766', 'P1103', and 'IAC 313', which were not significantly different from each other, whereas a smaller number of bunches per plant were reported on the rootstocks 'Freedom', 'Harmony', and 'SO4'.

The 'IAC 572' rootstock also favored greater branch and leaf fresh matter than the 'SO4' rootstock, confirming that the grapevines had greater vegetative development and vigor on that particular rootstock. However, there were no significant differences among the other rootstocks. The greater vigor observed in the grapevines grafted on 'IAC 572' favored the better performance of the other yield components. According to Silva et al. (2010), the 'IAC 572' rootstock exhibited greater vigor and vegetative development compared to 17 rootstocks. However, 'BRS Violeta' vines had greater vigor on the rootstocks 'SO4', 'Harmony', 'Paulsen 1103', and 'IAC 766', differing from the results obtained in this study and confirming that the response to the rootstock is genotype-specific, and is also affected by the edaphic and climatic conditions of each production region.

The grape bunches from the BRS Magna cultivar had a mean weight of $220 \mathrm{~g}$ when grafted on 'IAC 572', superior to the values obtained for this same cultivar by Ferreira et al. (2019) and for other juice grape cultivars such as Isabel Precoce, BRS Carmem, BRS Cora, IAC 138-22 Máximo (Silva et al., 2018), and Concord (BORGES et al. 2014). The results obtained represent an increase of $31 \%$ in bunch weight due to the rootstock used.
Physical traits of the bunches and berries, such as bunch length and width and berry weight, are largely under genetic control, exhibiting few variations within a determined grape cultivar. Nevertheless, these variables were also affected by the rootstock, and higher values were found in the grapevines grafted on 'IAC 572' (Table 2). These results are in accordance with those reported by Tecchio et al (2019a; 2019b) in the cultivars Vênus and Niágara Rosada, where the 'IAC 572' rootstock favored an increase in the weight and size of bunches and berries, as well as number of berries.

The grape bunch length of 'BRS Magna' on the 'IAC 572' rootstock was significantly different from its length on the rootstocks 'Paulsen 110', 'Freedom', 'Harmony', and 'SO4'. There were significant differences between 'IAC 572' and 'SO4' for bunch width and between 'IAC 572' and 'Harmony' for berry weight.

The responses to the rootstocks found in the bunch and berry weight and bunch size variables showed a tendency similar to the yield and number of bunches responses, which explains the positive correlations between the following variables: yield and number of bunches per plant showed positive correlation $(\mathrm{r}=0.71$, $p<.01)$, as well as yield and bunch length $(\mathrm{r}=0.61, \mathrm{p}<$ $.01)$, yield and bunch width $(\mathrm{r}=0.44, p<.01)$, and yield and bunch weight $(\mathrm{r}=0.49, p<.01)$.

The rootstock did not have an effect on soluble solids content. The average soluble solids value was $21.25^{\circ} \mathrm{Brix}$, which was greater than the values reported by other authors, e.g., between 17 and $19^{\circ}$ Brix in the BRS Magna cultivar (RITSCHEL et al. 2014; FERREIRA et al. 2020), and in other juice grape cultivars, such as Concord (Borges et al. 2014), Vênus (TECCHIO et al 2019a), Isabel Precoce, BRS Carmem, BRS Cora, and IAC 13822 Máximo (SILVA et al. 2018).

Other studies carried out in the Vale do Submédio São Francisco also indicated variations in SS in 'BRS Magna', which was affected more by the time of harvest in the year than because of the rootstock used (FERREIRA et al., 2019). However, in the same study, the rootstock 'IAC 572' and 'IAC 313' brought about greater soluble solids content than 'IAC 572' (NASSUR et al., 2014).

In contrast, titratable acidity showed significant differences among rootstocks, ranging from $0.43 \%$ in grapes harvested from the 'Harmony' rootstock up to $0.53 \%$ in 'Paulsen 1103 '. These values were lower than those observed by Ferreira et al. (2019) for studies on 'BRS Magna' conducted in this same region. The effects of the rootstock on the titratable acidity of the grape were also observed in other cultivars of Vitis labrusca and hybrids such as Vênus (TECCHIO et al 2019a), Niágara Rosada (TECCHIO et al 2019b), Concord (BORGES et al. 2014), Isabel Precoce, BRS Carmem, BRS Cora, and IAC 138-22 Máximo (Silva et al. 2018). 
The values obtained for soluble solids content and titratable acidity characterize the 'BRS Magna' grapes with high sugar content and low acidity (IPGRI UPOV OIV, 1997). The values of SS:TA were high in all the rootstocks, from 38.8 in grapes harvested on 'Paulsen 1103 ' to 49.8 on 'Harmony', with significant differences only between these rootstocks.

Principal component analysis indicated that most of the variability was retained in the first three principal components, which explained $80.3 \%$ of the variance and were used to plot the data in the two-dimensional space (Figure 2). Principal component 1 represented 46.1\% of the total variance, and the variables with greatest contribution in this component were bunch length (16.68\%), SS:TA (16.6\%), yield (15.9\%), and total acidity (15.7\%). Principal component 2 explained $21.6 \%$ of the total variance, and was mainly associated with soluble solids content (33.8\%), number of bunches (19.9\%), and bunch weight (17.9\%). Principal component 3, in turn, explained $13.0 \%$ of the variance and was represented mainly by the berry weight variable $(57.9 \%)$.
The scatterplot of the rootstock treatments and production cycles observed in Figure 2 showed a tendency of clustering of the rootstocks in accordance with the production cycle. In Figure 2A, the rootstocks evaluated in the second semester of 2015 were positioned in the upper left portion. The rootstocks in the production cycle of the second semester of 2017 were clustered in the upper central and right portion. In contrast, the rootstocks evaluated in the two production cycles of 2019 formed a group separated from the others and were positioned in the lower left portion, associated with the yield (Y), number of bunches (NB), and berry weight (WBe) variables.
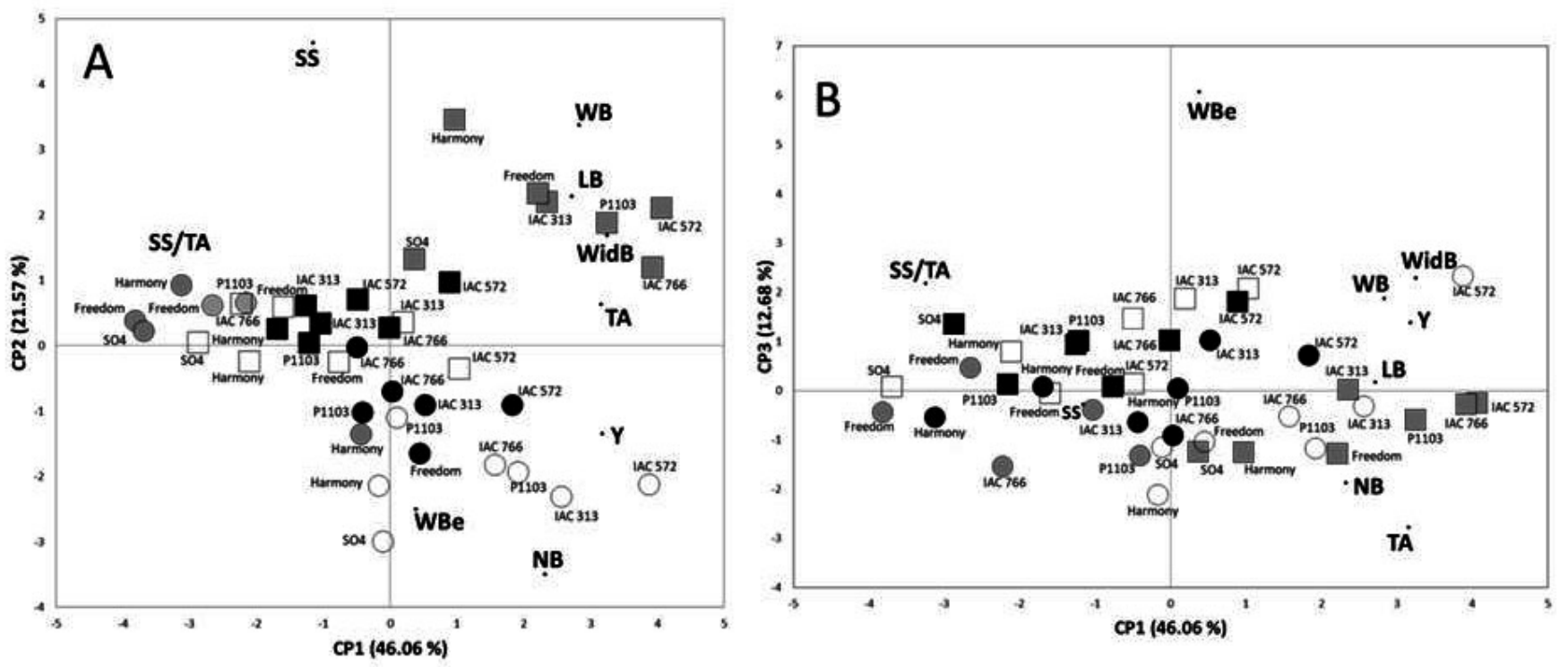

\begin{tabular}{|c|c|c|c|c|c|}
\hline 2015.2 & 2017.2 & 2018.1 & 2018.2 & 2019.1 & $\mathbf{2 0 1 9 . 2}$ \\
\hline$\square$ & $\square$ & $\square$ & $\bigcirc$ & $\bigcirc$ & $\bigcirc$ \\
\hline
\end{tabular}

Figure 2. PCA biplot showing distribution of the combinations among seven grapevine rootstocks and six growing seasons based on principal components 1 and 2 (A) and 1 and 3 (B). 2015.2: 11 Jun. to 17 Sep. 2015; 2017.2: 20 Jun. to 02 Oct. 2017; 2018.1: 27 Dec. 2017 to 04 Apr. 2018; 2018.2: 04 Jun. to 14 Sep. 2018; 2019.1: 12 Dec. 2018 to 12 May 2018; 2018.2: 07 May to 08 Aug. 2019. Y: yield ( $\left.\mathrm{t} \mathrm{ha}^{-1}\right)$; NB: number of bunches per plant; WB: bunch weight (g); WidB: bunch width (cm); LB: bunch length (cm); WBe: berry weight (g); SS: soluble solids content ( ${ }^{\circ}$ Brix); TA: titratable acidity (\%); SS/TA: soluble solids to titratable acidity ratio. 


\section{Conclusions}

The rootstock 'IAC 572' promoted greater vigor and yield performance and better physical traits of bunches and berries of 'BRS Magna' grape grown in the Vale do Submédio São Francisco. Conversely, the 'SO4' rootstock reduced the yield, vigor, weight, and size of bunches and should not be recommended in grafting of the BRS Magna cultivar under edaphic and climatic conditions similar to those of this study.

The 'BRS Magna' grapes had high soluble solids content, which was not affected by the rootstocks.

\section{References}

ALLEN, R.G.; PEREIRA, L.S.; RAES, D.; SMUTH, M. Crop evapotranspiration: guidelines for computing crop water requirements. Rome: FAO, 1998. 301p.

ALVARES, C.A.; STAPE, J.L.; SENTELHAS, P.C.; GONÇALVES, J.L. de M.; SPAROVEK, G. Koppen's climate classification map for Brazil. Meteorologische Zeitschrift, Berlin, v.22, p.711-728, 2014.

AOAC- Association of Official Agricultural Chemists. Official methods of analysis of the Association of the Agricultural Chemists. 18. ed. Gaithersburg: AOAC, 2010. $1025 \mathrm{p}$.

BORGES, R. de S.; ROBERTO, R.S.; YAMASHITA, F.; ASSIS, A.M. de; YAMAMOTOI, L.Y. Produção e qualidade de frutos de clones de videira 'Concord' sobre diferentes porta-enxertos. Pesquisa Agropecuária Tropical, Goiânia, v.44, n.2, p.198-204, 2014.

CUNHA, T.J.F.; SILVA, F.H.B.B. da; SILVA, M.S.L. da; PETRERE, V.G.; SÁ, I.B.; NETO, M.B. de O.; CAVALCANTI, A.C. Solos do Submédio do Vale do São Francisco: potencialidades e limitações para uso agrícola. Petrolina: Embrapa Semiárido, 2008. v. 211, 60 p.

FERREIRA, T. de O.; , COSTA, R.R. ; FÉLIX, D.T.; ANDRADE NETO, E.R. de, C.; MACEDO, M. de; LIMA, M.A.C. de. Quality and antioxidant potential of 'BRS Magna' grapes harvested in the first half of the year under different training systems and rootstocks in a tropical region. Ciência \& Agrotecnologia, Lavras, v.43, p.e029518, 2019.
FERREIRA. T. de O.; LIMA. A. de S.; BIASOTO. A.C.T.; RYBKA, A.C.P.; LIMA, M.A.C. de. Rootstock for the BRS Magna grapevine grown in a tropical region affects the quality of the stored juice. Revista Ciência Agronômica, Fortaleza, v.51, n.3, p.e20186562, 2020.

IPGRI, UPOV, OIV. Descriptors for grapevine (Vitis spp.). Rome: International Plant Genetic Resources Institute, 1997.

LEÃO, P.C. de S.; REGO, J.I. de S.; NASCIMENTO, J.H.B.; SOUZA, E.M. de C. Yield and physicochemical characteristics of BRS Magna and Isabel Precoce grapes influenced by pruning in the São Francisco river valley. Ciência Rural, Santa Maria, v.48, n.6, p.e20170463, 2018.

LIMA, M dos S.; SILANI, I.S.V.; TOALDO, I.M.; CORREAA, L.C.; BIASOTO, A.C.T. Phenolic compounds. organic acids and antioxidant activity of grape juices produced from new Brazilian varieties planted in the Northeast Region of Brazil. Food Chemistry, London, v.161, p.94-103, 2014.

MELLO, L.M.R. de; MACHADO, C.A.E. Vitivinicultura brasileira: panorama 2019. Brasília (DF): Embrapa, 2020. (Comunicado Técnico, 214). Disponível em: https://www.embrapa.br/en/busca-de-publicacoes/-/ publicacao/1124189/vitivinicultura-brasileirapanorama-2019\#. Acesso em: 26 jan. 2021.

NASSUR, R. de C.; RESENDE, M.; PEREIRA, G.E.; ALVES, J.A.; LIMA, L.C. de O. Chemical characteristics of grape juices from different cultivar and rootstock combinations. Pesquisa Agropecuária Brasileira, Brasília (DF), v.49, n.7, p.540-545, 2014.

RITSCHEL, P.; MAIA, J.D.G.; CAMARGO, U.A.; ZANUS, M.C.; SOUZA, R.T. de; FAJARDO, T.V.M. 'BRS MAGNA' - a novel grape cultivar for juice making, with wide climatic adaptation. Crop Breeding and Applied Biotechnology, Londrina, v.14, n.4, p.266-269, 2014.

SILVA, T.P. da; PIO, R.; SALIBE, A.B.; DALASTRA, I.M.; STANGARLIN, J.R.; KUHN, O.J. Avaliação de porta-enxertos de videira em condições subtropicais. Bragantia, Campinas, v.69, n.1, p.93-97, 2010. 
SILVA, M.J.R. da; PAIVA, A.P.M.; JUNIOR, A.P.; SÁNCHEZ, C.A.P.C.; CALLILI, D.; MOURA, M.F.; LEONEL, S.; TECCHIO, M.A. Yield performance of new juice grape varieties grafted onto different rootstocks under tropical conditions. Scientia Horticulturae, New York, v.241, p.194-200, 2018.
TECCHIO, M.A.C.; SILVA, M.J.R. da; PAIVA, A.P.M.; MOURA, M.F.; TERRA, M.M.; PIRES, E.J.P.; SARITA, L. Phenological, physicochemical, and productive characteristics of 'Vênus' grapevine onto rootstocks. Pesquisa Agropecuária Brasileira, Brasília (DF), v.54, p.e00335, 2019a.

TECCHIO, M.A.C.; SILVA, M.J.R. da; SÁNCHEZ, C.A.P.C.; WATANABLE, C.Y.; MOURA, M.F.; LEONEL, S.; JUNIOR, A.P. The influences of rootstock and pruning seasons on productive and physicochemical traits of 'Niagara Rosada' grape. Australian Journal of Crop Science, Lismore, v.13, n.7, p.1211-1214, 2019b. 